\title{
Online searching trend on Covid-19 using Google trend: infodemiological study in Malaysia
}

\author{
Tengku Adil Tengku Izhar ${ }^{1} \cdot$ Torab Torabi $^{2}$
}

Received: 22 June 2021 / Accepted: 16 October 2021/Published online: 29 January 2022

(C) Bharati Vidyapeeth's Institute of Computer Applications and Management 2021

\begin{abstract}
Since January 2020, the emergence of Covid-19 has sparked a worldwide search for information about Covid-19. People frequently use the internet to search the information on the virus. However, the pandemic have triggered the information-seeking trends among public. As a result, large amount of information could lead to infodemic. It will create public concerned such as panic and paranoid because this information spread rapidly. The aim of this study is to analyze information about Covid-19 that has been searched in Malaysia. We investigated online search behavior related to the Covid-19 outbreak among public by using Google Trends to understand public searching behavior on Covid-19. The findings from this study can be used as a tool to monitor public searching activities on Covid-19, which could predict future action regarding the outbreak.
\end{abstract}

Keywords Covid-19 - Google trend · Infodemic . Infodemiological $\cdot$ Searching behavior

\section{Introduction}

In November 2019, coronavirus disease of 2019 (Covid-19) has become a global pandemic [13]. Since then, millions of people use internet to search for information on Covid-19 [19]. In early 2020, people all over the world are compelled

Tengku Adil Tengku Izhar tengkuadil@yahoo.co.uk

1 Faculty of Information Management, Universiti Teknologi MARA (UiTM), UiTM Selangor, Shah Alam, Malaysia

2 Department of Computer Science and Information Technology, La Trobe University, Melbourne, Australia to stay at home because of the outbreak pandemic. They rely on the internet for work and communication. Covid-19 has impacts many people in their daily life, which includes going to work and socializing $[10,11,44]$. In order to maintain physical distancing, many of us have to work from home in order to stop the spread of the Covid-19. At the same time, the need to obtain information about the disease and its prevention has also become important [23]. As a result, a massive information epidemic has become another challenge to fight against Covid-19 $[1,4,6,24,29,35]$.

The lockdown force people in switching from face-toface interactions to the digital interaction $[3,10,16]$. In relation to the spread of Covid-19, a massive infodemic spread virally over the world can result to many issues [25]. Previous evidence suggests that the internet could expand the issue of infodemic that might cause exaggerated panic among public [8]. This is because there is not enough attention to fully understand the issue of infodemic $[2,10,33]$. The infodemic is caused by high volume of information that supply variety number of information based on current demand of information about Covid-19 $[8,9,33]$.

In Malaysia, the spread of Covid-19 has cause a massive change in term of daily life and activity. This massive change also reflects the online behavior among Malaysian when searching the information on Covid-19. Until March 31, 2021, Malaysia recorded 572,357 total cases with 79,523 active cases with 2,779 total death cases reported by Ministry of Health Malaysia (http://covid-19.moh.gov.my/ ). As a result, issue such as misleading information is very difficult to handle. People rely on information in order to feel safer. At the same time, people search the information on Covid-19 to understand the current situation before they could come out with any decision such as what Standard of 
Procedure (SOP) need to be followed, the way the virus could be spreaded, information on the symptoms or the information on the new variant of the Covid-19.

Nowadays, the Covid-19 infodemic is getting more attention by researchers $[2,8,9,39]$. The term infodemiological such as an online searching activities on Google are widely used to understand the searching behaviors. Most of the information that has been searched focus on public health $[5,9,27,28,38,46]$. However, the number of massive information could lead to panic that impact on the public wellbeing [23]. It is important to manage information from the internet to reduce erroneous information that gives rise on misinformation $[17,25,30]$. Therefore, information needs to be cleared and easy to understand. At the same time, media such as social media and commercial news must be utilized in order for information to be regularly updated [15]. This is to understand the need of the public during the outbreak [34, 45]. In digital world, it is likely that online searching play an even more important role during the post-pandemic world [42, 43, 46].

The aim of this paper is to understand public engagement in searching information on Covid-19. In order to achieve this aim, we evaluate information on Covid-19 using Google Trends. The results from this study will improve the understanding of the searching trends for affected populations in order to monitor public searching activities toward Covid-19. The results will improve the understanding of public need during this outbreak.

\section{Literature review}

People are trying to understand the virus by seeking information from a variety of sources, including commercial media and the internet [23]. For example, Indonesia recorded the increase of 50\% viewers on television as their primary source of information on Covid-19 [40]. This happened in the United Kingdom and Australia [14]. In the United Kingdom, people watch BBC News more frequently [7]. Other platforms such as social media also become an important tool for people to search the information on Covid-19 [18, 23].

People only use credible sources of information about Covid-19 in order to avoid any misinformation and fake news. The usage of internet is increased dramatically. People prefer to check on their symptoms on the internet rather than seeing their doctor. This happened commonly in Indonesia [23].

Online searching on Covid-19 increased in February 2020 all over the world starting in China [36]. For example, online searching on Covid-19 increased in Taiwan after first imported case reported on January 21, 2020 [37]. The searching activities online increase two weeks later before the information on the virus also accessible on other platform such as video and radio-based news reporting [20]. In addition, the searches for face masks also increase. Massive purchasing of face masks appeared to be causing public panic. People become panic as information on mask shortages is wildly spreaded which forced the Taiwanese government to loosen restrictions on surgical mask imports [32].

Li et al. [21] reported that search engines were able to predict the Covid-19 outbreak from 1 to 2 weeks earlier than that the case in India which may have influenced their searching activity. The internet searching pattern depend on the influence of various factors, such as peer groups, mass media and social media interactions [41].

In Malaysia, the protective consumables of mask and hand sanitizer were the topic of interest for the public [22]. Following the news reports of Covid-19, masks and hand sanitizer becomes necessary item after the first case reported in Malaysia. The online searching on the awareness of hand hygiene and hand washing is increasing among the public. At the same time, searching trends on the public concern about the adequacy of supply and the availability of goods as their costs soared to previously unimaginable rates. The searching activity online increased one more time in the middle of March 2020 after the government announced the Movement Control Order (MCO) starting on March 18, 2020. Table 1 shows that most of the previous study focused on public understanding on the virus. The result shows that the understanding of the virus will reflect public attitude toward the virus. For example, if public aware about the virus in term on how it spreads, they might be more careful when they go out.

\section{Methods}

Methodology used in this study is adapted from the previously described framework by Mavragani and Ochoa [26]. The framework shows the relationship for the region selection and time period selection to retrieve data from Google Trends. In this paper, data is collected and normalized from Google Trends (https://trends.google.com/ trends). The scale of search are range of 0 (very low) to 100 (very high). A 100 mean the peak population of the search and 0 mean the lowest population of the search.

We used Google Trends to explore internet search activity related to Covid-19 from May 31, 2020 to May 31, 2021. We retrieved data using the keyword "Covid-19 Malaysia". Using this keyword, we managed to understand the trend of information seeking among public in selected region in Malaysia.

Data is filtered and analysed to identify relevant information in Google Trends. Data is mapped, filtered and 
Table 1 Covid-19 related information searching

\begin{tabular}{llll}
\hline Authors & Symptom of virus & Understand the virus & Preventive measures \\
\hline Lim et al. [22] & & - & - \\
Venkatesh and Grandhi [41] & & - & - \\
Li et al. [22] & - & - \\
Pan and Chiang [31] & - & - & \\
Strzelecki [36] & - & - & \\
Limilia and Pratamawaty [23] & - & - \\
Iman [18] & & - \\
Ellis [7] & & - \\
Harrison [14] &
\end{tabular}

analysed to extract relevant information on Covid-19 in Malaysia. This process also discussed by Ghani and Kamal [12], which include five stages and tasks:

- Data input-databases/datasets

- Mapping

- Filtering

- Analytic

- Data output-Relevant information

\subsection{Stage 1: data input}

Data are collected from databases. Google Trends can be defined as large continuous of data storage. Internet users create high volume of data and make it difficult to analyse this data for certain query. For example, 250 million information is search per day create high amounts of data and the amounts are increasing every day [12]. A reliable analysis approach for this data is a big challenge. The framework will extract data from Google Trends to be mapped in order to select data that can be considered relevant.

\subsection{Stage 2: mapping}

This stage includes the process to map data that already selected in stage 1 . The process is to identify specific query from databases (Google trends). The query is mapped to identify the flow of data from the databases.

\subsection{Stage 3: filtering}

This stage includes the processes involved in refining data that are already mapped during the previous stage. The process is to filter selected query from databases in order to consider data that relate to the query is relevant. This process identifies relevant data to be analysed.

\subsection{Stage 4: analytic}

In this stage, data analysis will be exercised.

\subsection{Stage 5: data output}

In the final stage, the matched results will be presented as the output resulted. The results will be the most relevant results that can be used for the decision-making process.

\section{Results and discussion}

Figure 1 shows the nation wide interest in Covid-19 for 12 months from May 31, 2020. The results show that most of the searching activity increased drastically between August 2020 and September 2020. The activity is high because of the second wave of the pandemic in Malaysia. Figure 1 also shows that the searching activity dropped in November 2020 to January 2021. This result has caused a major inconsistency of public to follow the Standard Operation Procedure (SOP) because the public becomes comfortable with the current number of new cases. Many people are not following the SOP anymore. As a result, they do not show any interest in searching the information on Covid-19 anymore.

Figure 2 shows the activity based on 16 regions in Malaysia. The results show that many regions have the highest searching activity in September 2020 because the regions have the highest new cases with new clusters. Therefore, public are still interested in searching the information on Covid-19. However, some regions with low cases are not interested in searching the information about the virus anymore. This has cause a major issues such as people are comfortable and they do not follow the SOP anymore such as in Pahang, Perak, Perlis, Johor and Selangor. Searching activity on Covid-19 is still high in some states such as Kedah and Sabah because during that particular time, this two states dealing with high number of cases in Malaysia. 
Fig. 1 Searching activity nationwide in Malaysia

\section{Malaysia Covid-19 Searching Trends}

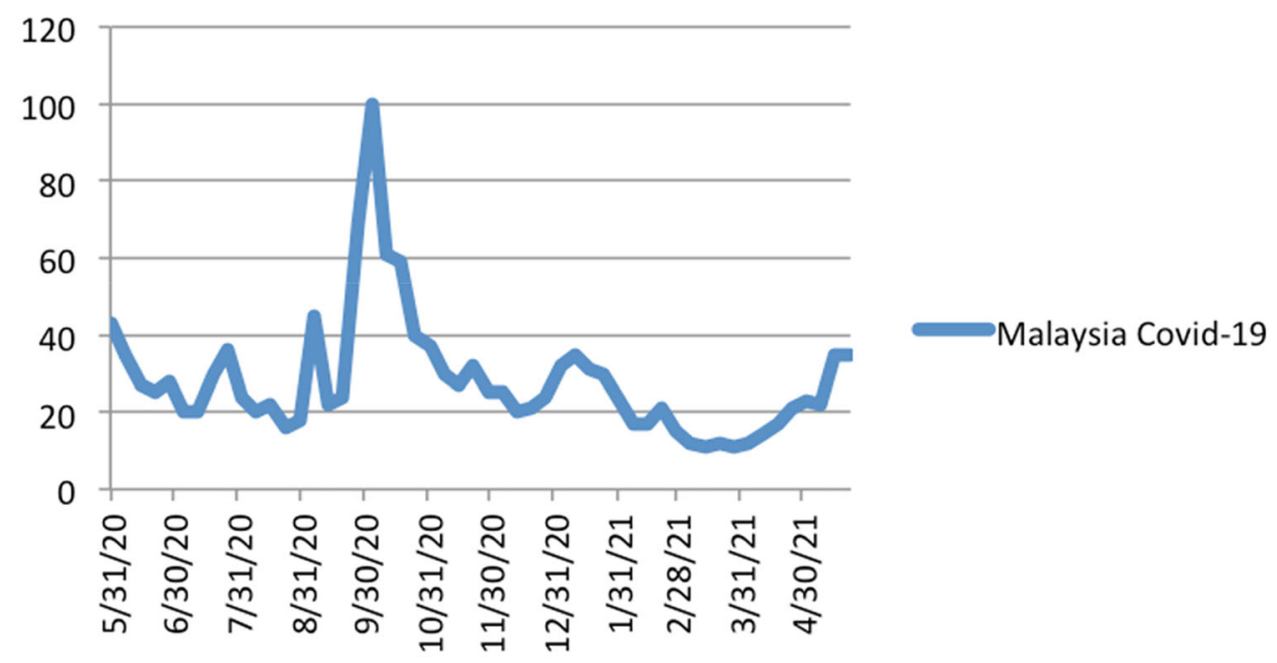

Malaysia Covid-19 Searching Trends by State (Region)

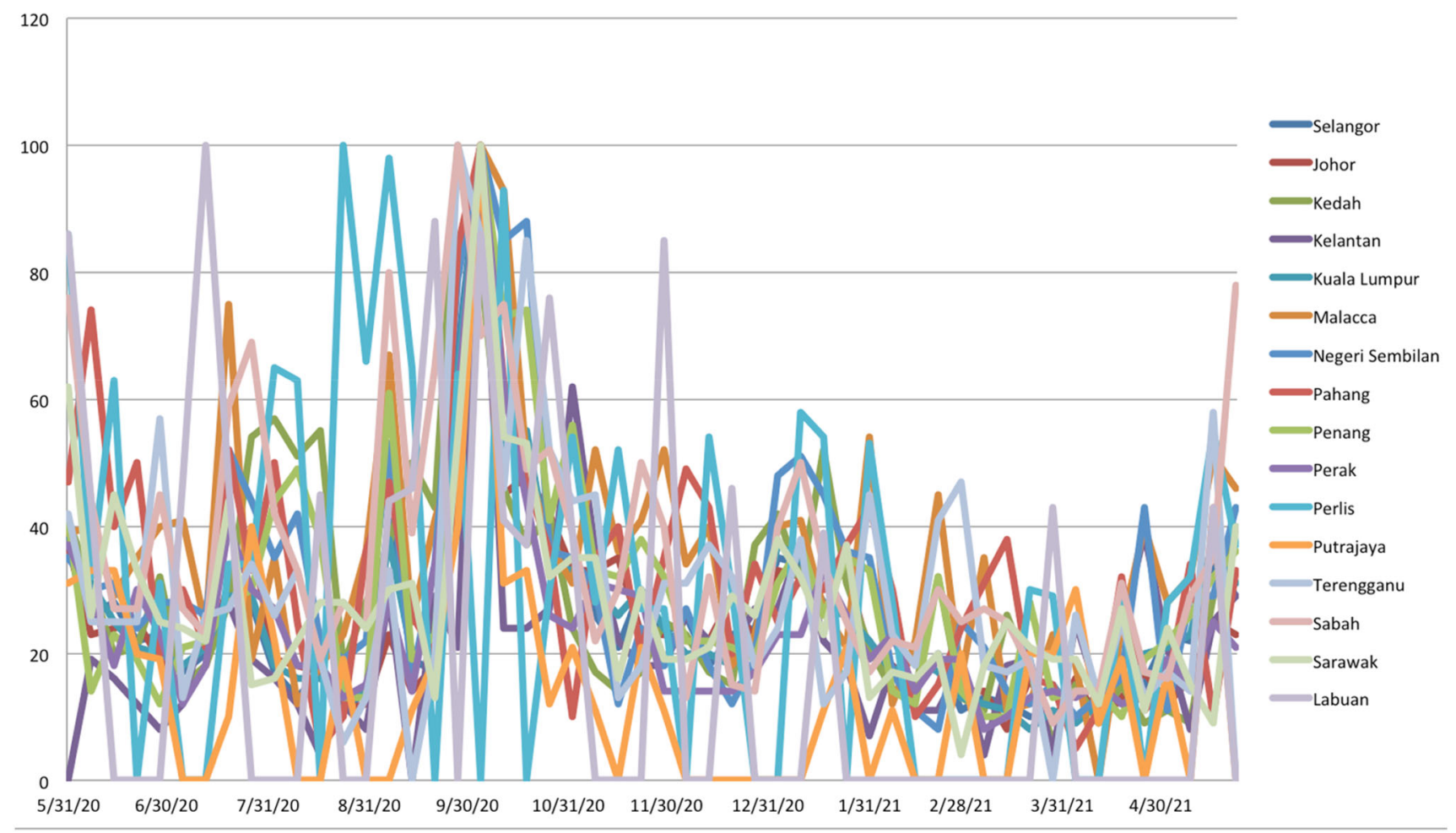

Fig. 2 Searching activity according to region

The results help the decision-making process in order to make sure that people are still following the SOP because the cases are still high in Malaysia. The low number in certain regions has cause a major outbreak, which cause from people who are not following SOP anymore. As a result, it causes a third wave of new cases in early 2021.
The trends in searching information on Covid-19 reflect the public responsibility in obeying the SOP. The results show the number of searching activity is high only at certain part in Malaysia, which the public is concerned about the spread of the virus. The number of new cases getting higher until the end of 2020 as the number continuously getting high but the number of searching activity 
is low. As mentioned earlier, people get comfortable and they feel they do not need extra information regarding the virus. They started to live with the virus but they forget to apply the new norm in their daily activity.

\section{Conclusion}

This paper has addressed how the Covid-19 pandemic has acted as a breaching experiment and has exposed several important caveats and stubborn issues related to digitalization [10]. Therefore, the result is important to make sure that public are still aware and interested in findings information on Covid-19 in order to make sure they are stay alert. The impact of lack of interest in searching more information on current situation might decrease public awareness. As a result, Malaysia are currently on another wave and lockdown with average current cases are 20,000 cases. This study still has some limitation to consider. Google Trends captures the search behavior of people that use the Google search engine [48]. Therefore, it is difficult to get exact number of people that really aware about the pandemic and use the online searching such as Google to get information about the virus because some people might use other search engine too. In conclusion, data on public searching trend on the virus are very important and need to be paid more attention in order to understand the searching trend which might help to control the spread of Covid-19 in Malaysia.

\section{References}

1. Allmann K (2020) Covid-19 is increasing digital inequality: We need human connectivity to close the digital divide. In The Oxfordshire Digital Inclusion Project. https://www.law.ox.ac.uk/ research-and-subject-groups/oxfordshire-digital-inclusion-pro ject/blog/2020/04/covid-19-increasing. Accessed 13 Apr 2020

2. Barnett E, Cheung A, Loudon J (2021) Maintaining quality while adapting to a virtual work environment during the Covid-19 pandemic. J Med Imaging Radiat Sci 52:9-10

3. Bestsennyy O, Gilbert G, Harris A, Rost J (2020) Telehealth: a quarter-trillion-dollar post-Covid-19 reality? Healthcare systems \& services. McKinsey \& Company, Angola

4. Campbell D, Siddique H (2020) Covid-19 death rate in England higher among BAME people. The Guardian. https://www.the guardian.com/world/2020/jun/02/covid-19-death-rate-in-englandhigher-among-bame-people. Accessed 02 June 2020

5. Chen Y, Zhang Y, Xu Z, Wang X, Lu J, Hu W (2019) Avian influenza A (H7N9) and related internet search query data in China. Science Rep 9(1):10434

6. Rovetta A, Bhagavathula AS (2020) Covid-19-related web search behaviors and infodemic attitudes in Italy: infodemiological study. JMIR Public Health Surveill. 6(2):e19374

7. Ellis M (2020) Adults media lives: covid-19 early-lockdown interviews. www.knowledgeagency.co.uk. Accessed 6 May 2021
8. Eysenbach G (2020) How to fight an infodemic: the four pillars of infodemic management. J Med Internet Res 22(6):e21820

9. Eysenbach G (2013) SARS and population health technology. J Med Internet Res 5(2):e14

10. Faraj S, Renno W, Bhardwaj A (2021) Unto the breach: what the Covid-19 pandemic exposes about digitalization. Inform Organ 31:100337

11. Garfinkel H (1967) Studies in ethnomethodology. Prentice-Hall, Englewood Cliffs, NJ, p 288

12. Ghani NA, Kamal SSM (2015) A sentiment-based filteration and data analysis framework for social media. In: 5th International conference on computing and informatics ICOCI. Istanbul, Turkey, p 632-637

13. Gong K et al (2021) A multi-center study of Covid-19 patient prognosis using deep learning-based CT image analysis and electronic health records. Eur J Radiol 139:109583

14. Harrison J (2020) Covid and the media. Should we believe everything we hear or read? https://richmondpulse.org/2020/08/ 25/social-media-news-dont-believe-everything-read-internet/. Retrieved 15 May 2021

15. Holmes BJ, Henrich N, Hancock S, Lestou V (2009) Communicating with the public during health crises: experts' experiences and opinions. J Risk Res 12(6):793-807

16. Hollander JE, Carr BG (2020) Virtually perfect? Telemedicine for Covid-19. N Engl J Med 382:1679-1681

17. Hu Z et al (2020) The covid-19 infodemic: infodemiology study analyzing stigmatizing search terms. J Med Internet Res 22(11): $1-166$

18. Iman (2020) Survei Kedaikopi: Mayoritas Masyarakat Indonesia Anggap Virus Corona Ancaman Serius. https://rri.co.id/nasional/ 796708/survei-kedaikopimayoritas-masyarakat-indonesia-ang gap-virus-corona-ancaman-serius. Accessed 6 May 2021

19. International Telecommunications Union/UNESCO (2020). The state of broadband 2017: broadband catalyzing sustainable development. https://www.itu.int/dms_pub/itu-s/opb/pol/S-POLBROADBAND.18-2017-PDF-E.pdf. Accessed 01 Aug 2020

20. Keller M et al (2009) Use of unstructured event-based reports for global infectious disease surveillance. Emerg Infect Dis 15(5):689-695

21. Li C, Chen LJ, Chen X, Zhang M, Pang CP, Chen H (2020) Retrospective analysis of the possibility of predicting the Covid19 outbreak from Internet searches and social media data, China, 2020. Euro Surveill 25(10):2000199

22. Lim JL, Ong CY, Xie B, Low LL (2020) Estimating information seeking-behaviour of public in Malaysia during Covid-19 by using Google trends. Malays J Med Sci 27(5):202-204

23. Limilia P, Pratamawaty BB (2020) Google trends and information seeking trend of COVID-19 in Indonesia. Jurnal ASPIKOM 5(2):188-205

24. Mavragani A, Ochoa G, Tsagarakis KP (2018) Assessing the methods, tools, and statistical approaches in google trends research: systematic review. J Med Internet Res 20(11):e270

25. Mavragani A, Ochoa G (2018) Infoveillance of infectious diseases in USA: STDs, tuberculosis, and hepatitis. J Big Data $5(1): 1-23$

26. Mavragani A, Ochoa G (2019) Google trends in infodemiology and infoveillance: methodology framework. J Med Internet Res 21(5):e13439

27. Mollema L et al (2015) Disease detection or public opinion reflection? Content analysis of tweets, other social media, and online newspapers during the measles outbreak in The Netherlands in 2013. J Med Internet Res 17(5):e128

28. Mohamed NA (2018) Knowledge, attitude and practice on batsborne diseases among village residents: a pilot study. Med Health 13(2):48-57 
29. WHO (2020) Novel coronavirus (2019-nCoV) situation report13. World Health Organization. URL: https://www.who.int/docs/ default-source/coronaviruse/situation-reports/20200202-sitrep-13ncov-v3.pdf. Accessed 17 May 2021

30. Nuti SV et al (2014) The use of google trends in health care research: a systematic review. PLOS ONE 9(10):e109583

31. Pan TY, Chiang YC (2020) Taiwan loosens restrictions on surgical mask imports. GlobalSecurity.org; Available from: https:// www.globalsecurity.org/secu-rity/library/news/2020/02/sec-200203cna03.html. Accessed 02 Mar 2020

32. Putri Limilia P, Pratamawaty BB (2020) Google trends and information seeking trend of covid-19 in Indonesia. J Aspikom 5:188

33. Ratzan SC, Sommariva S, Rauh L (2020) Enhancing global health communication during a crisis: lessons from the Covid-19 pandemic. Public Health Res Prac 2:3022010

34. Reynolds B, Seeger MW (2005) Crisis and emergency risk communication as an integrative model. J Health Commun 10(1):43-55

35. Simcock R et al (2020) Covid-19: global radiation oncology's targeted response for pandemic preparedness. Clin Transl Radia Oncol 22:55-68

36. Strzelecki A (2020) Infodemiological study using Google trends on coronavirus epidemic in Wuhan, China. Int J Online Biomed Eng. https://doi.org/10.3991/ijoe.v16i04.13531

37. Taiwan CDC (2020) Press releases: Covid-19. Available from: https://www.cdc.gov.tw/En/Bulletin/List/7tUXjTBf6paRvrhElmrPg. Accessed 17 Feb 2020

38. Tang L, Bie B, Park S, Zhi D (2018) Social media and outbreaks of emerging infectious diseases: a systematic review of literature. Am J Infect Control 46(9):962-972

39. Tangcharoensathien $\mathrm{V}$ et al (2020) Framework for managing the covid-19 infodemic: methods and results of an online, crowdsourced WHO technical consultation. J Med Internet Res 22(6): 19659

40. Utama F (2020) KPI: Lonjakan Pemirsa TV hingga 50\%, TV menjadi garda terdepan informasi Covid-19 kepada Masyarakat—iNews Portal. https://www.inews.id/news/nasional/kpi-lon jakan-pemirsa-tv-hingga-50-tv. Accessed 17 May 2021

41. Venkatesh U, Gandhi PA (2020) Prediction of covid-19 outbreaks using google trends in india: a retrospective analysis. Healthc Inform Res 26:175-184

42. Walsham G (2012) Are we making a better world with ICTs? Reflections on a future agenda for the IS field. J Inform Technol 27(2):87-93

43. Wang L (2020). In tech-savvy China, cash-carrying elderly are being left behind. In Sixth Tone. June 6 http://www.sixthtone. com/news/1006499. Accessed 25 Nov 2020

44. Whillans A, Perlow L, Turek A (2021) Experimenting during the shift to virtual team work: learnings from how teams adapted their activities during the Covid-19 pandemic. Inform Organ 31:100343

45. Yunus NR, Rezki A (2020) Kebijakan pemberlakuan lock down sebagai antisipasi penyebaran corona virus covid-19. SALAM: Jurnal Sosial Dan Budaya Syar-I 7(3):227

46. Zeraatkar K, Ahmadi M (2018) Trends of infodemiology studies: a scoping review. Health Inform Lib J 35(2):91-120

47. Zheng Y, Walsham G (2021) Inequality of what? An intersectional approach to digital inequality under Covid-19. Inform Organ 31:100341

48. Rovetta A, Bhagavathula AS (2020) Covid-19 related web search behaviors and infodemic attitudes in Italy: infodemiological study. JMIR Public Health Surveill 6(2):e19374 